\title{
Aglomerasi Disparitas Pembangunan Wilayah Provinsi
} Banten

\author{
${ }^{*}$ Vadilla Mutia Zahara1, Suhroji Adha², Djaka Adiwinata3 , Mira Nurhikmat ${ }^{4}$ \\ ${ }^{1}$ Universitas Sultan Ageng Tirtayasa, Indonesia \\ 2,3,4 Universitas Faletehan, Serang, Banten, Indonesia \\ E-mail: ${ }^{*}$ adillamutia@untirta.ac.id,suhroji90@gmail.com,djaka.adwinata@gmail.com, \\ nurhikmat.mira24@gmail.com
}

\begin{tabular}{l}
\hline Article Info \\
\hline Article History \\
Received: 2021-05-12 \\
Revised: 2021-07-22 \\
Published: 2021-08-14 \\
\\
Keywords: \\
Regional Disparities; \\
Agglomeration; \\
PDRB.
\end{tabular}

\begin{abstract}
Development is basically to improve the welfare of the community based on social justice and carried out in a sustainable manner. The success of a region's development is measured by high economic growth, however, fast/high economic growth will lead to inequality in income distribution, this is because it does not pay attention to whether the growth is greater or less than the population growth rate or changes in the economic structure. of this study is to analyze regional development disparities and determine the effect of per capita PDRB and agglomeration on regional development disparities in Banten province. This study uses the panel data regression method by calculating the disparity of 8 regencies/cities in Banten Province during the period 2016 - 2019. The results of the disparity analysis show that from 8 regencies/cities, in general the level of regional development disparity is still at a value of $<1$ based on the calculation of the willamson index. , while from the analysis of the two variables, the results of the Per capita GRDP have a negative and significant effect and the agglomeration variable has a positive effect.
\end{abstract}

\begin{tabular}{l}
\hline Artikel Info \\
\hline Sejarah Artikel \\
Diterima: $2021-05-12$ \\
Direvisi: $2021-07-22$ \\
Dipublikasi: $2021-08-14$
\end{tabular}

Kata kunci: Disparitas Wilayah; Aglomerasi; PDRB.

\begin{abstract}
Abstrak
Pembangunan pada dasarnya adalah untuk meningkatkan kesejahteraan masyarakat yang berazaskan keadilan sosial dan dilakukan secara berkelanjutan. Keberhasilan pembangunan suatu wilayah salah satunya diukur dari pertumbuhan ekonomi yang tinggi, akan tetapi, pertumbuhan ekonomi yang cepat/ tinggi akan menimbulkan ketimpangan distribusi pendapatan hal ini dikarenakan tidak memperhatikan apakah pertumbuhan tersebut lebih besar atau lebih kecil dari tingkat pertumbuhan penduduk atau perubahan struktur ekonomi, Tujuan dari penelitian ini adalah untuk menganalisis disparitas pembangunan wilayah serta mengetahui pengaruh PDRB Perkapita dan aglomerasi terhadap disparitas pembangunan wilayah provinsi Banten. Penelitian ini menggunakan metode regresi data panel dengan menghitung disparitas 8 Kabupaten/ Kota di Provinsi Banten selama periode tahun 2016 - 2019. Hasil analisis disparitas menunjukan dari 8 kabupaten/kota, secara umum tingkat disparitas pembangunan wilayah masih berada pada nilai $<1$ berdasarkan perhitungan indeks willamson, sedangkan dari analisis kedua variabel didapatkan hasil PDRB Perkapita berpengaruh negatif dan signifikan dan variabel Aglomerasi berpengaruh positif.
\end{abstract}

\section{PENDAHULUAN}

Pembangunan merupakan suatu proses multidimensional yang melibatkan perubahanperubahan besar dalam struktur sosial, sikap mental dan lembaga-lembaga nasional termasuk pula percepatan/ akselerasi pertumbuhan ekonomi, pengurangan ketimpangan, dan pemberantasan kemiskinan yang absolut, Pembangunan pada dasarnya adalah untuk meningkatkan kesejahteraan masyarakat yang berazaskan keadilan sosial dan dilakukan secara berkelanjutan (Andrianto \& Iskandar, 2019). Pembangunan merupakan proses multidimensial meliputi perubahan struktur sosial, sikap hidup masyarakat dan kelembagaan untuk meningkatkan pertumbuhan ekonomi, pengurangan kemiskinan serta ketimpangan pendapatan (Korua et al., 2016) Tujuan ekonomi suatu negara adalah untuk meningkatkan kesejahteraan masyarakat. Negara Sedang Berkembang (NSB) merupakan negara-negara yang memerlukan perhatian lebih dalam pembangunan ekonomi. Penyebab semakin meluasnya perhatian terhadap pembangunan di negara sedang berkembang ialah keinginan untuk mengejar ketertinggalan dan meningka-tkan kesejahteraan mereka. Peningkatan kesejahteraan masyarakat mencerimkan partum-buhan 
ekonomi yang meningkat dan distribusi pendapatan yang merata. Pertumbuhan ekonomi suatu daerah diukur dengan Produk Domestik Bruto (PDRB) dan laju pertumbuhan ekonomi atas dasar harga konstan (Nurlina \& Chaira, 2017). Pertumbuhan ekonomi yang cepat akan menimbulkan ketimpangan distribusi pendapatan hal ini dikarenakan tidak memperhatikan apakah pertumbuhan tersebut lebih besar atau lebih kecil dari tingkat pertumbuhan penduduk atau perubahan struktur ekonomi, ketimpangan distribusi pendapatan ini akan menciptakan kesenjangan, terutama kesenjangan daerah (regional disparity). Kesenjangan ini timbul dikarenakan tidak adanya pemerataan dalam pembangunan ekonomi.

Ketidakmertaan pembangunan ini disebabkan karena adanya perbedaan antar daerah satu dengan yang lainnya. Akibat dari perbedaan ini, kemampuan suatu daerah dalam mendorong proses pembangunan juga menjadi berbeda, terjadinya ketimpangan antar daerah ini membawa implikasi terhadap kesejahteraan masyarakat antar wilayah yang memiliki implikasi terhadap formulasi kebijakan pembangunan wilayah yang dilakukan oleh Pemerintah Daerah (Sjafrijal, n.d.).

Tabel 1. PDRB, Jumlah Penduduk, dan PDRB Per Kapita Provinsi Banten Tahun 2016-2019

\begin{tabular}{cccc}
\hline Tahun & $\begin{array}{c}\text { PDRB (Juta } \\
\text { Rupiah) }\end{array}$ & $\begin{array}{c}\text { Jumlah } \\
\text { Penduduk } \\
\text { (Jiwa) }\end{array}$ & $\begin{array}{c}\text { PDRB Per } \\
\text { kapita (Ribu } \\
\text { Rupiah) }\end{array}$ \\
\hline 2016 & 389543932,29 & 12203148 & 31921,59 \\
\hline 2017 & 412639618,30 & 12448160 & 33148,64 \\
\hline 2018 & 436581428,06 & 12689736 & 34404,30 \\
\hline 2019 & 459828497,36 & 12927316 & 35570,30 \\
\hline \multicolumn{4}{c}{ Sumber:Badan Pusat Statistik Provinsi Banten 2019 }
\end{tabular}

Tabel diatas menggambarkan peningkatan PDRB, Jumlah Penduduk dan PDRB Per kapita Provinsi Banten dari tahun 2016 sampai 2019. Nilai PDRB cenderung meningkat dari tahun ketahun dan PDRB perkapita juga terjadi peningkatan yang tinggi pada setiap tahunnya., Menurut (Michael P. Todaro Stephen C. Smith, 2015), ketimpangan memiliki dampak positif dan dampak negatif, dampak positif dari adanya ketimpangan adalah dapat mendorong wilayah lain yang kurang maju untuk dapat bersaing dan meningkatkan pertumbuhannya guna menumbuhkan kesejahteraannya. Sedangkan dampak negatif dari ketimpangan yang ekstrim antara lain inefisiensi ekonomi, melemahkan stabilitas sosial dan solidaritas, serta ketimpangan yang tinggi pada umumnya dipandang tidak adil.

\section{a. Teori Pertumbuhan Neo-Klasik}

Teori pertumbuhan Neo-Klasik dikembangkan oleh Robert Solow dan Trevor Swan (1956). Model Solow-Swan menggunakan unsur pertumbuhan penduduk, akumulasi kapital, kemajuan teknologi, dan besarnya output yang saling berinteraksi dalam proses pertumbuhan ekonomi. (Robinson Tarigan, 2012), Model Neo-Klasik dipelopori oleh Geogre H. Bort (1960). Menurut model ini pertumbuhan ekonomi suatu daerah akan sangat ditentukan oleh kemampuan daerah tersebut untuk meningkatkan produksinya, Sedangkan kegiatan produksi suatu daerah tidak hanya ditentukan oleh potensi daerah yang bersangkutan, tetapi juga ditentukan pula oleh mobilitas tenaga kerja dan mobilitas modal antar daerah (Sjafrijal, n.d.), Karena kunci utama pertumbuhan ekonomi daerah adalah peningkatan kegiatan produksi, maka mengukuti Richardson (1978), Model NeoKlasik ini dapat dapat diformulasikan mulai dari fungsi produksi. Dengan menganggap bahwa fungsi produksi adalah dalam bentuk Cobb-Douglas, maka dapat ditulis:

$$
Y=A K^{\alpha} L^{\beta}, \alpha+\beta=1
$$

Dimana $\mathrm{Y}$ melambangkan PDRB, $\mathrm{K}$ dan $\mathrm{L}$ masing-masingnya adalah modal dan tenaga kerja. Karena analisa menyangkut pertumbuhan maka semua variabel dianggap adalah fungsi waktu ( $\mathrm{t}$ ). Dengan mengambil turunan matematika persamaan (2.1) terhadap variabel t diperoleh:

$$
y=\alpha+\alpha k+(1-\alpha) l
$$

Dimana $=\mathrm{Dy} / \mathrm{dt}$ menunjukan peningkatan PDRB (pertumbuhan ekonomi), $\alpha=\mathrm{Da} / \mathrm{dt}$ menunjukan perubahan teknologi produksi (secara netral), $\mathrm{k}=\mathrm{dK} / \mathrm{dt}$ yang menunjukkan nilai investasi dan $\mathrm{I}=\mathrm{Dl} / \mathrm{dt}$ menunjukan pembahasan jumlah dan peningkatan kualitas tenaga kerja, Penganut Model Neo-Klasik dalam Sjafrizal (2008) beranggapan bahwa mobilitas faktor produksi, baik modal maupun tenaga kerja, pada permulaan proses pembangunan adalah kurang lancar. Akibatnya, pada saat itu modal dan tenaga kerja ahli cenderung terkonsentrasi di daerah yang lebih maju sehingga ketimpangan pembangunan regional cenderung melebar (divergence). Akan tetapi bila proses pembangunan terus berlanjut, dengan semakin baiknya prasarana dan fasilitas komunikasi maka mobilitas modal dan tenaga 
kerja tersebut akan semakin lancar (Agustus et al., 2015), dengan demikian, nantinya setelah negara yang bersangkutan telah maju maka ketimpangan pembangunan regional akan berkurang (convergence).

\section{b. Teori Aglomerasi}

Marshall menjelaskan istilah aglomerasi yaitu sebagai agglomeration economies atau dalam disebut sebagai industri yang terlokalisir (localized industries). Menurut (Fikanti Zuliastri, Wiwiek Rindayati, 2014) aglomerasi adalah konsentrasi spasial dari aktivitas ekonomi di kawasan perkotaan karena penghematan akibat lokasi yang berdekatan (economies of proximity) yang diasosiasikan dengan kluster spasial dari perusahaan, para pekerja dan konsumen.

Perroux mengatakan bahwa ditinjau dari aspek lokasinya, pembangunan daerah adalah tidak merata dan cenderung terjadi aglomerasi (pemusatan) pada pusat-pusat pertumbuhan. Pada gilirannya pusat-pusat pertumbuhan tersebut akan mempengaruhi daerah-daerah yang lambat perkembangannya. Hirchman dan Myrdal mengatakan bahwa setelah pembangunan tertentu dicapai, maka perbedaan dalam kemakmuran antar daerah cenderung akan hilang. Dalam proses ini, maka dua mekanisme pokok yang adalah disebut dengan Spread dan Backwash Effect. Hal-hal inilah yang dapat menjadi indikator terjadinya aglomerasi. Aglomerasi terjadi karena adanya hubungan saling saling membutuhkan produk diantara berbagi industri, seperti tersedianya fasilitas tenaga listrik, air, perbengkelan, jalan raya, juga terdapat tenaga kerja terlatih, (Robinson Tarigan, 2012)

Keuntungan aglomerasi (Agglomeration Economies) pada dasarnya merupakan kekuatan utama dari sebuah pertumbuhan. Alasannya adalah karena dapat memberikan keuntungan eksternal baik dalam bentuk penurunan biaya atau peningkatan peluang pasar bagi para pengusaha yang beroperasi dalam pusat tersebut. Karena itu, dapat dikatakan bahwa apabila keuntungan aglomerasi yang dapat dihasilkan oleh sebuah pusat pertumbuhan cukup besar, maka pusat tersebut akan sulit berkembang dengan pesat. Akan tetapi sebaliknya, pusat tersebut akan sulit berkembang bilamana keuntungan aglomerasi yang dapat dihasilkan sangat terbatas atau tidak ada sama sekali (Sjafrizal, 2008), Keuntungan aglomerasi baru dapat muncul bila dapat muncul bilamana terdapat keterkaitan yang erat antara kegiatan ekonomi yang ada pada konsentrasi tersebut baik dalam bentuk keterkaitan dengan output (Backward Linkages) atau keterkaitan dengan output (Forward Linkages).

Konsentrasi kegiatan ekonomi antar daerah yang cukup tinggi akan cenderung mendorong meningkatnya ketimpangan pembangunan antar wilayah sebab proses pembangunan daerah akan lebih cepat pada daerah dengan konsentrasi kegiatan ekonomi yang lebih tinggi. Sedangkan konsentrasi kegiatan ekonomi rendah proses pembangunan akan berjalan lebih lambat. Oleh karena itu, ketidakmerataan ini menimbulkan ketimpangan pembangunan antar wilayah (Sjafrizal, 2008).

\section{c. Hipotesis Kuznets}

Simon Kuznets (1995) (Adi Sutrisno, 2013) membuat hipotesis adanya kurva U-Terbalik (inverted $U$ curve) bahwa mula-mula ketika pembangunan dimulai, distribusi pendapatan akan makin tidak merata, namun setelah mencapai suatu tingkat pembangunan tertentu, distribusi pendapatan makin merata. Menurut Kuznets, pertumbuhan ekonomi adalah kenaikan kapasitas dalam jangka panjang dari negara yang bersangkutan untuk menyediakan berbagai barang ekonomi kepada penduduknya. Kenaikan kapasitas itu sendiri ditentukan atau dimungkinkan oleh adanya kemajuan atau penyesuaianpenyesuaian teknologi, institusional (kelembagaan), dan ideologis terhadap berbagai tuntutan keadaan yang ada (Subandi, 2012).

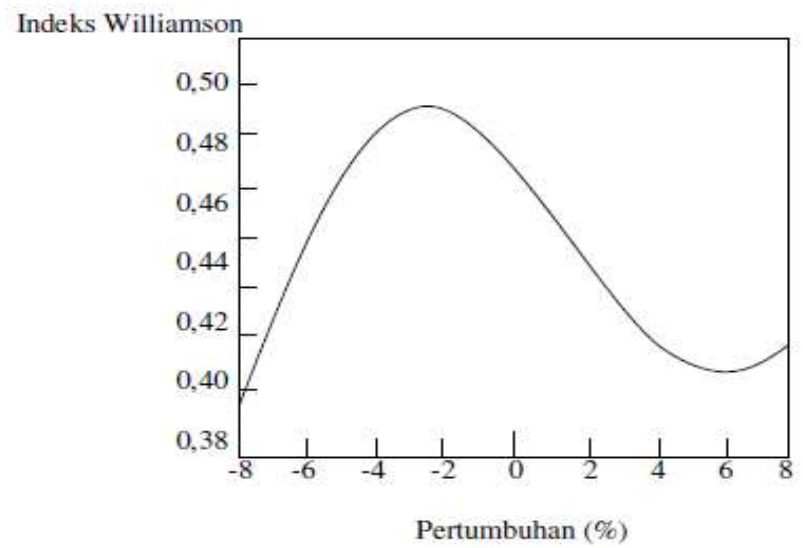

Gambar 1. Kurva Hubungan antara Indeks Williamson dengan Pertumbuhan PDRB Sumber: Sutarno dan Mudrajad Kuncoro, 2003 
Hasil dari penelitian Sutarno dan Mudrajad Kuncoro (2003) menunjukkan kurva berbentuk U-Terbalik, dimana pada partumbuhan awal ketimpangan memburuk dan pada tahap-tahap berikutnya ketimpangan menurun, namun pada suatu waktu akan terjadi peningkatan ketimpangan lagi dan akhirnya akan menurun lagi sehingga dapat dikatakan peristiwa tersebut seperti berulang kembali, Pada akhirnya analisis Kuznets (Michael P. Todaro Stephen C. Smith, 2015) menyatakan bahwa pertumbuhan di negaranegara maju tidak menyebabkan negaranagara berkembang ikut tumbuh, hal ini dikarenakan negara berkembang tidak mampu mengikuti pertumbuhan negaranegara maju tersebut, sehingga terjadilah kesenjangan antar negara maju dan negara berkembang dalam pertumbuhan ekonominya. Kritik utama terhadap kuva Kuznets adalah hasil ini sangat sensitif terhadap ukuran inequality dan pemilihan set data. Dengan melakukan pemilihan yang berbeda, seseorang bisa mendapat kurva U, kurva U terbalik, atau tidak ada hubungan sama sekali (Subandi, 2012)

\section{d. Ketimpangan Pembangunan Wilayah}

Ketimpangan pada kenyataannya tidak dapat dihilangkan dalam pembangunan suatu daerah. Adanya ketimpangan, akan memberikan dorongan kepada daerah yang terbelakang untuk dapat berusaha meningkatkan kualitas hidupnya agar tidak jauh tertinggal dengan daerah sekitarnya (Rifky, 2018). Selain itu daerah-daerah tersebut akan bersaing guna meningkatkan kualitas hidupnya, sehingga ketimpangan dalam hal ini memberikan dampak positif. Akan tetapi ada pula dampak negatif yang ditimbulkan dengan semakin tingginya ketimpangan antar wilayah. Dampak negatif tersebut berupa inefisiensi ekonomi, melemahkan stabilitas sosial dan solidaritas, serta ketimpangan yang tinggi pada umumnya dipandang tidak adil (Michael P. Todaro Stephen C. Smith, 2015) Adapun faktor-faktor yang menetukan ketimpangan pembangunan antar wilayah antara lain konsentrasi kegiatan ekonomi antar daerah, mobilitas barang dan faktor produksi antar daerah serta alokasi investasi antar wilayah dengan wilayah lainnya. Bahkan kebijakan yang dilakukan oleh suatu daerah dapat pula mempengaruhi ketimpangan pembangunan regional. Oleh karena itu untuk menghitung tingkat ketimpangan wilayah digunakan beberapa metode yaitu indeks Williamson.

\section{e. Indeks Williamson}

Untuk mengukur ketimpangan ekonomi antara sektor pertanian, industri dan jasa digunakan nilai Indeks Ketimpangan Williamson (IW). Nilai IW berkisar antara 0 sampai 1 yang memiliki arti semakin tinggi nilai IW maka ketimpangan semakin tinggi dan sebaliknya jika semakin mendekati 0 (nol) maka semakin merata.

$$
\mathrm{IW}=\frac{\sqrt{\Sigma(Y i-Y)^{2} * f i / n}}{Y}
$$

\section{Keterangan: \\ IW= Indeks Williamson \\ $\mathrm{Yi}=$ Pendapatan perkapita di masing-masing Kabupaten di Provinsi Banten \\ $\mathrm{Y}=$ Pendapatan perkapita di Provinsi Banten \\ $\mathrm{Fi}=$ Jumlah penduduk di masing-masing Kabupaten di Provinsi Banten \\ $\mathrm{n}$ = Jumlah penduduk di Provinsi Banten}

Ketimpangan menyebabkan inefisiensi ekonomi, sebab ketimpangan yang tinggi, tingkat tabungan secara keseluruhan di dalam perekonomian cenderung rendah, karena tabungan yang tinggi biasanya ditemukan pada kelas menengah. Meskipun orang kaya dapat menabung dalam jumlah lebih besar, mereka biasanya menabung dalam bagian yang lebih kecil dari pendapatan mereka, dan tentunya menabung dengan bagian yang lebih kecil lagi dari pendapatan marginal mereka (Michael P. Todaro Stephen C. Smith, 2015) Dampak negatif inilah yang menyebabkan ketimpangan yang tinggi yang menjadi masalah dalam pembangunan untuk menciptakan kesejahteraan suatu wilayah, pada tahap awal Provinsi Banten memiliki pertumbuhan dan distribusi pendapatan yang rendah, namun pada tahap selanjutnya pertumbuhan dan distribusi pendapatan Provinsi Banten relatif meningkat. Hal ini sejalan dengan Hipotesis Kuznet mengenai U-Terbalik, dimana pada tahap-tahap awal distribusi pendapatan cenderung memburuk, namun pada tahap selanjutnya hal tersebut akan membaik (Iskandar \& Saragih, 2018), hal ini diindikasikan bahwa pembangunan yang terjadi di Provinsi Banten belum terlaksana secara merata, Banyak faktor yang mempengaruhi ketimpangan suatu wilayah. Myrdal dalam (Jhingan, 2012) mengemukakan bahwa ketimpangan yang terjadi dalam suatu 
wilayah dikarenakan besarnya dampak balik (Backwash Effect) baik berupa perpindahan modal atau investasi menyebabkan ketimpangan semakin besar antara wilayah satu dengan wilayah lainnya, Berdasarkan penjelasan tersebut maka pertanyaan penelitian ini antara lain:

1) Bagaimanakah analisis disparitas pembangunan wilayah yang terjadi di Kabupaten/Kota Provinsi Banten selama periode penelitian?

2) Bagaimanakah pengaruh PDRB Per Kapita dan Aglomerasi terhadap disparitas pembangunan wilayah di Provinsi Banten?

\section{METODE PENELITIAN}

Penelitian ini adalah penelitian Kuantitatif dengan Jenis data yang digunakan dalam penelitian ini adalah data kuantitatif dan sumber data yang digunakan adalah data sekunder, Sumber data berasal dari Badan Pusat Statistik Provinsi Banten dan literatur serta informasi tertulis yang berasal dari instansi terkait, Analisis yang digunakan dalam penelitian ini adalah analisis regresi. Analisis regresi digunakan untuk menjawab pengaruh variabel PDRB per kapita dan aglomerasi terhadap disparitas pembangunan wilayah antar Kabupaten/Kota di Provinsi Banten.

\section{HASIL DAN PEMBAHASAN}

\section{A. Analisis Pembangunan Disparitas Wilayah}

Tabel nilai RD (Regional Disparity) < 1 berikut ini menggambarkan tingkat disparitas yang rendah atau tingkat pemerataan yang baik, dan sebaliknya nilai RD besar menggambarkan bahwa tingkat disparitas tinggi atau $>1$, maka terjadi ketidakmerataan disuatu wilayah yang mengakibatkan daerah tersebut sangat timpang.

Tabel 2. Analisis Indeks Williamson Kabupaten/kota di Provinsi Banten Tahun 2008-2011 (persen)

\begin{tabular}{ccccc}
\hline Provinsi & $\mathbf{2 0 1 6}$ & $\mathbf{2 0 1 7}$ & $\mathbf{2 0 1 8}$ & $\mathbf{2 0 1 9}$ \\
\hline Banten & 0,771 & 0,771 & 0,774 & 0,791 \\
\hline & & Sumber: Olah data hasil penelitian
\end{tabular}

\section{B. Uji Hausman}

Adapun hasil uji Hausman dijelaskan pada tabel di bawah ini:

Tabel 3. Hasil Uji Hausman

\begin{tabular}{cccc}
\hline Test Summary & $\begin{array}{c}\text { Chi-Sq. } \\
\text { Statistic }\end{array}$ & $\begin{array}{c}\text { Chi-Sq. } \\
\text { d.f. }\end{array}$ & Prob. \\
\hline $\begin{array}{c}\text { Cross-section } \\
\text { random }\end{array}$ & 0.927185 & 2 & 0.0290 \\
\hline \multicolumn{4}{c}{ Sumber: Olah data hasil penelitian }
\end{tabular}

Berdasarkan Tabel diatas, diperoleh nilai probabilitas pada uji Hausman sebesar 0.0290 , dengan demikian nilai $p$-value $\chi^{2}$ $(0.0290)<0.05$, maka dapat disimpulkan bahwa $\mathrm{H}_{0}$ di tolak yang berarti model menggunakan fixed effect.

\section{Hasil Regresi}

Adapun hasil uji regresi linear yang dilakukan dijelaskan dalam table berikut ini:

Tabel 4. Hasil Uji Regresi

\begin{tabular}{llllc}
\hline \multicolumn{5}{l}{ Total panel (unbalanced) observations: 30 } \\
\hline Variable & Coefficient & Std. Error & t-Statistic & Prob. \\
LNPDRB & -0.832157 & 0.233225 & -3.568047 & 0.0019 \\
LNAG & 0.307594 & 0.331983 & 0.926537 & 0.3652 \\
C & 11.21545 & 3.622777 & 3.095816 & 0.0057 \\
\hline \multicolumn{5}{c}{} \\
\hline Effects Specification \\
R-squared & 0.744882 & Mean dependent var & -1.685589 \\
Adjusted R-squared & 0.630079 & S.D. dependent var & 0.947748 \\
S.E. of regression & 0.576431 & Akaike info criterion & 1.997279 \\
Sum squared resid & 6.645451 & Schwarz criterion & 2.464345 \\
Log likelihood & -19.95918 & Hannan-Quinn criter. & 2.146697 \\
F-statistic & 6.488355 & Durbin-Watson stat & 2.420061 \\
Prob(F-statistic) & 0.000255 & & \\
\hline \multicolumn{5}{c}{ Sumber: Olah data hasil penelitian }
\end{tabular}

\section{Keterangan:}

R-squared $=0,744882$

F-statistic $=6,488355$

$\mathrm{D}-\mathrm{W} \quad=2,420061$

\section{Pengujian Asumsi Klasik}

Pengujian asumsi dilakukan untuk memastikan bahwa model yang dipilih telah memenuhi asumsi yang telah ditentukan, antara lain:

\section{Uji Multikolonearitas}

Berikut disajikan data hasil uji multikoloneritas melalui Matriks Korelasi Uji Multikolinearitas:

Tabel 5. Matriks Korelasi Uji Multikolinearitas

\begin{tabular}{lll} 
& LNPDRB & LNAG \\
\hline LNPDRB & 1.000000 & 0.644945 \\
\hline LNAG & 0.644945 & 1.000000 \\
\hline \multicolumn{2}{r}{ Sumber: Olah data hasil penelitian }
\end{tabular}

Dari hasil korelasi matriks diatas dapat dilihat bahwa koefisien matriks korelasi antar variabel bebas lebih kecil dari 0.80 sehingga tidak terdapat hubungan linear antar variabel atau tidak terjadi gejala multikolinearitas.

\section{Uji Heteroskedastisitas}

Berikut disajikan data hasil uji Heteroskedastisitas: 
Tabel 6. Hasil Uji White

\begin{tabular}{ll}
\hline Obs*Squared & Chi-squared $\left(\boldsymbol{\chi}^{2}\right)$ tabel \\
\hline 22,34 & 43,77 \\
\hline
\end{tabular}

Tabel diatas menunjukan bahwa dalam penelitian ini memiliki observasi sebanyak 30 pada alfa 5 persen, nilai $\chi^{2}$ tabel adalah sebesar 43,77. Dibandingkan dengan nilai Obs*squared sebesar 22,34. Dari hasil tersebut dapat disimpulkan bahwa nilai Obs*squared lebih kecil dari nilai Chi-Squared tabel, maka dalam penelitian ini terbebas dari heteroskedastisitas.

\section{Uji Auotokorelasi}

Table berikut menunjukan bahwa nilai du lebih kecil dari D-W dan D-W kurang dari 4 dikurangi du atau menurut Damodar Gujarati 2010 apabila nilai du < dw < 4-du. Maka nilai statistik Durbin-Watson berada pada kriteria tidak ada autokorelasi.

Tabel 7. Hasil pengujian nilai Durbin-Watson

\begin{tabular}{ccccc}
\hline Dl & du & D-W & 4-du & 4-dl \\
\hline 1.3039 & 1.5736 & 2.4200 & 2.4264 & 2.6961 \\
\hline \multicolumn{4}{c}{ Sumber: Olah data hasil penelitian }
\end{tabular}

\section{Pengujian Statistik}

Pengujian statistic dilakukan untuk menguji validitas model pengaruh PDRB Perkapita dan aglomerasi terhadap disparitas pembangunan wilayah, disajikan dalam bentuk table berikut ini:

Tabel 8. Hasil Uji t Statistik

\begin{tabular}{lllll} 
Variabel & t-Statistik & t-Tabel & Prob. & Kriteria \\
\hline $\begin{array}{l}\text { PDRB } \\
\begin{array}{l}\text { Perkapita } \\
(\mathrm{X} 1)\end{array}\end{array}$ & -3.568047 & 2,052 & 0.0019 & Signifikan \\
\hline $\begin{array}{l}\text { Aglomer } \\
\text { asi (X2) }\end{array}$ & 0.926537 & 2,052 & 0.3652 & $\begin{array}{l}\text { Tidak } \\
\text { Signifikan }\end{array}$ \\
\hline & & Sumber: Olah data hasil penelitian
\end{tabular}

\section{Keterangan:}

Signifikan pada $\alpha=5$ persen, dengan $\mathrm{df}=\mathrm{n}-\mathrm{k}$ $(30-3)=27$, maka $t$-tabel $=2.052$

Berikut penjelasan dari hasil uji t statistik dari masing-masing variabel independen:

1. Hasil uji hipotesis PDRB Perkaita $\left(X_{1}\right)$ terhadap Disparitas Pembangunan Wilayah $(\mathrm{Y})$, dengan $\alpha=5$ persen, maka hipotesis yang digunakan:
- $\mathrm{H}_{0}: \beta_{1}<0$; tidak terdapat pengaruh antara PDRB Perkapita terhadap Disparitas Pembangunan Wilayah.

- Ha : $\beta_{1}>0$; terdapat pengaruh antara PDRB Perkapita terhadap Disparitas pembangunan wilayah.

Pengembalian keputusan:

- Jika t-hitung > t-tabel maka $\mathrm{H}_{0}$ ditolak, artinya secara parsial PDRB Perkapita berpengaruh signifikan terhadap disparitas pembangunan wilayah.

- Jika t-hitung $<\mathrm{t}$-tabel maka $\mathrm{H}_{0}$ diterima, artinya secara parsial PDRB Perkapita tidak berpengaruh signifikan terhadap disparitas pembangunan wilayah.

2. Hasil uji hipotesis Aglomerasi $\left(\mathrm{X}_{2}\right)$ disparitas pembangunan wilayah (Y), dengan $\alpha=5 \%$, maka hipotesis yang digunakan:

- $\mathrm{H}_{0}: \beta_{1}<0$; tidak terdapat pengaruh antara aglomerasi terhadap disparitas pembangunan wilayah.

- Ha : $\beta_{1}>0$; terdapat pengaruh antara aglomerasi terhadap disparitas pembangunan wilayah.

Pengambilan keputusan:

- Jika t-hitung > t-tabel maka $\mathrm{H}_{0}$ ditolak, artinya secara parsial aglomerasi berpengaruh signifikan terhadap disparitas pembangunan wilayah.

- Jika t-hitung < $\mathrm{t}$-tabel maka $\mathrm{H}_{0}$ diterima, artinya secara parsial aglomerasi tidak berpengaruh signifikan terhadap disparitas pembangunan wilayah.

Berdasarkan hasil perhitungan uji t tersebut dapat disimpulkan bahwa pada alpa 5 persen $(\alpha=5$ persen) variabel independen PDRB Perkapita (X1) memiliki nilai $t_{\text {hitung }}$ sebesar 3.568047 dan $t_{\text {tabel }}$ sebesar 2,052 berati nilai $t_{\text {hitung }}<\mathrm{t}_{\text {tabel }}$ maka variabel X1 tidak sigifikan. Variabel aglomerasi (X2) memiliki nilai $t_{\text {hitung }}$ sebesar 0.926537 dan $t_{\text {tabel }}$ sebesar 2,052 yang berarti nilai $t_{\text {hitung }}<\mathrm{t}_{\text {tabel }}$ maka variabel $\mathrm{X} 2$ tidak signifikan.

\section{E. Pengujian F- Statistik}

Nilai F-statistik dalam table yang diperoleh adalah sebesar 6.488355 persen dengan probabilitas F-statistik sebesar 0.000255 . Dengan demikian dapat disimpulakan bahwa PDRB Perkapita (X1) dan Aglomerasi (X2) secara serentak mempunyai pengaruh yang signifikan terhadap disparitas pembangunan wilayah (Y). 


\section{F. Koefisien Determinasi $\mathbf{R}^{2}$}

Berdasarkan hasil perhitungan regresi antara PDRB Perkapita(X1) dan Aglomerasi (X2) diperoleh nilai $\mathrm{R}^{2}=0.744882$ menandakan bahwa disparitas pembangunan wilayah (Y) mampu dijelaskan secara serentak oleh PDRB Perkapita dan aglomerasi sebesar 74 persen sedangkan sisanya sebesar 26 persen dijelaskan oleh faktor-faktor lain yang tidak masuk dalam model. Sementara nilai $\mathrm{R}=$ 0.7890 berarti bahwa tingkat korelasi antara variabel $\mathrm{X}_{1}, \mathrm{X} 2$, terhadap variabel $\mathrm{Y}$ adalah kuat dan arahnya positif. Hal ini ditandai dengan nilai R yang semakin mendekati 1 .

\section{G. Interpretasi Hasil dan Pembahasan}

Dari data yang diperoleh dilakukan pengolahan data dengan menggunakan Metode Ordinary Least Square (OLS) dan model yang digunakan adalah Fixed Effect Model (FEM) untuk mengetahui faktor yang mempengaruhi disparitas pembangunam wilayah di provinsi Banten Tahun 2008-2011. Variabel dependen yang digunakan adalah disparitas wilayah (RD), dan variabel independen yang digunakan adalah PDRB Perkapita dan aglomerasi. Berdasarkan hasil perhitungan regresi dengan model Fixed Effect pengaruh PDRB Perkapita dan Aglomerasi terhadap disparitas pembangunan wilayah di Provinsi Banten sebagai berikut:

\section{$\operatorname{LnRD}=11,21545-(-0,832157) * \operatorname{LnPDRB}$ $(X 1)+0,307594 * \operatorname{Ln} A g(X 2)$}

Nilai konstanta sebesar 11,21545 hal tersebut berarti apabila terdapat pengaruh dari variabel-variabel bebas yang digunakan dalam penelitian ini, maka disparitas pembangunan wilayah meningkat sebesar 11,21545 persen, Analisis selanjutnya adalah semua variabel yang terdapat dalam model persamaan regresi yaitu PDRB Per kapita (X1) dan Aglomerasi (X2), dan di uji secara signifikansi sebagai berikut:

\section{PDRB Per Kapita (X1)}

Hasil uji statistik memperlihatkan bahwa variabel PDRB Perkapita berpengaruh negatif dan tidak signifikan dalam mempengaruhi disparitas pembangunan wilayah di provinsi Banten. Adapun nilai koefisien regresi PDRB Perkapita (X1) sebesar -0,832157. Selanjutnya, dengan melihat tingkat signifikansi dimana tingkat kepercayaan 95\% atau dengan $\alpha=0,05$ maka nilai probabilitasnya sebesar 0.0019 dimana nilainya $<0,05$. Hal ini PDRB Perkapita berpengaruh negatif dan signifikan.

Hubungan negatif yang terjadi antara PDRB Perkapita dengan disparitas wilayah disebabkan oleh pendapatan perkapita degan jumlah penduduk disebagian besar kabupaten/kota di Provinsi Banten masih merata. Namun untuk kota Cilegon dan Kota Tangerang pendapatan masyarakatnya tidak merata. Dapat disimpulkan bahwa secara keseluruhan pendapatan perkapita masyarakat menurut kabupaten/kota di provinsi Banten adalah mengalami disparitas wialayah dalam taraf yang rendah. Hasil ini sesuai dengan Hipotesa Neo-Klasik dalam (Sjafrizal,2008) yang mengatakan pada permulaan proses pembangunan suatu wilayah, ketimpangan pembangunan antar wilayah cenderung meningkat. Setelah itu, bila proses pembangunan terus berlanjut, maka secara berangsur-angsur disparitas pembangunan wilayah tersebut akan menurun. Hasil penelitian menunjukkan bahwa PDRB Perkapita berpengaruh negatif terhadap disparitas pembangunan wilayah, dengan demikian hipotesis penelitian ini diterima.

\section{Aglomerasi (X2)}

Tingkat aglomerasi ditunjukkan oleh analisis Indeks Spesialisasi dengan menggunakan proporsi tenaga kerja sektor industri suatu wilayah untuk memberikan gambaran bahwa aglomerasi menurut kabupaten/kota di Provinsi Banten tahun 2016-2019. Aglomerasi industri cenderung terjadi di Kabupaten Tangerang, Kabupaten Serang dan Kota Tangerang Selatan. Hal ini terjadi karena kabupaten/ kota tersebut masing-masing memiliki keunggulan wilayah yang mendorong terciptanya pemusatan atau aglomerasi. Sesuai dengan pendapat Robinson Tarigan (2008), aglomersi terjadi karena adanya hubungan saling membutuhkan produk diantara berbagai industri seperti tersedianya fasilitas (tenaga listrik, air, perbengkelan, jalan raya, dan tenaga kerja terlatih).

Hasil uji statistik memperlihatkan bahwa variabel Aglomerasi berpengaruh positif dan signifikan dalam mempengaruhi disparitas pembangunan wilayah di provinsi Banten. Hal ini diketahui dengan melihat tingkat signifikansi dimana tingkat 
kepercayaan 95 pesen ratau dengan $\alpha=$ 0,05 , dan nilai probabilitasnya sebesar 0.3652 dimana nilainya $>0,05$. Koefisien regresi Aglomerasi (Ag) sebesar 1,307594 persen. Dengan demikian untuk variabel aglomerasi (X2) tidak signifikan karena nilai probabilitasnya lebih dari 0,05 persen

\section{SIMPULAN}

Berdasarkan hasil analisis dan hasil pembahasan maka dapat disimpulkan sebegai berikut:

1) Tingkat disparitas pembangunan wilayah di Provinsi Banten tahun 2016-2019 menurut Kabupaten/Kota setiap tahunnya mengalami penurunan. Hal ini sejalan dengan hipotesis Kuznet bahwa pada tahap awal pembangunan tingkat disparitas tinggi namun seiring dengan perkembangan tahun ke tahun pertumbuhan semakin membaik dan disparitas semakin menurun. Dari 8 kabupaten/kota, secara umum menunjukan nilai indeks Williamson $<1$.

2) Variabel yang mempengaruhi disparitas pembangunan wilayah dalam penelitian ini secara signifikan adalah PDRB Perkapita dan aglomerasi. Dalam penelitian ini PDRB Perkapita berpengaruh negatif dan signifikan dan variabel Aglomerasi berpengaruh positif dengan signifikansi dimana tingkat kepercayaan 95 persen atau dengan $\alpha=0,05$, dan nilai probabilitasnya sebesar 0.3652 dimana nilainya $>0,05$. Maka variabel aglomerasi berpengaruh positif dan tidak signifikan. Hal ini disebabkan karena aglomerasi industri di Provinsi Banten masih lemah, dengan kata lain aglomerasi industri di Provinsi Banten tidak dapat mempengaruhi untuk mengurangi disparitas wilayah menurut kabupaten/kota di Provinsi Banten.

\section{DAFTAR RUJUKAN}

Adi Sutrisno. (2013). Analisis ketimpangan pendapatan dan pengembangan sektor unggulan di kabupaten dalam kawasan barlingmascakeb tahun 2007-2010. 2(4), 446-455.

Agustus, N., Rizfal, A., Masduki, U., Efriadi, A. R., \& Masduki, U. (2015). Inequality and Fiscal Decentralization. 5(2), 717-736.

Andrianto, I., \& Iskandar, D. A. (2019). Program Pembangunan Dalam Konvergensi/Divergensi Wilayah. Jurnal Litbang Sukowati: Media Penelitian Dan
Pengembangan, 4(1), 13. https://doi.org/10.32630/sukowati.v4i1.10 1

Badan Pusat Statistik. Data jumlah Tenaga Kerja Sektor Industri usia $15>$. BPS Provinsi Banten

Badan Pusat Statistik. PDRB Per kapita Menurut Kabupaten/ Kota Atas Dasar Harga Konstan dari tahun 2008-2019. BPS Provinsi Banten.

Badan Pusat Statistik. PDRB Atas Dasar Harga Konstan dari Tahun 2008-2019. BPS Provinsi Banten.

Fikanti Zuliastri, Wiwiek Rindayati, A. A. (2014). ANALISIS FAKTOR YANG MEMENGARUHI AGLOMERASI INDUSTRI UNGGULAN DAERAH DAN HUBUNGANNYA DENGAN DAYA SAING INDUSTRI DAERAH. 3(2), 8-22.

Iskandar, A., \& Saragih, R. (2018). Analisis Kondisi Kesenjangan Ekonomi Daerah: Studi Kasus Kabupaten/Kota Di Sulawesi Selatan. Info Artha, 2(1), 37-52. https://doi.org/10.31092/jia.v2i1.232

Jhingan. (2012). EKONOMI PEMBANGUNAN DAN PERENCANAAN. RAJAWALI.

Korua, F. S., Rumate, V. A., \& Siwu, H. F. D. (2016). Pengaruh Investasi Pemerintah Terhadap Pertumbuhan Ekonomi Melalui Tenaga Kerja Sebagai Intervening Variabel Di Provinsi Sulawesi Utara Tahun 2003-2013. Jurnal Berkala Ilmiah Efisiensi, 16(01), 410417.

Lyncolin, Arsyad. 2004. Ekonomi Pembanguan. STIE, YKPN, Yogyakarta

Michael P. Todaro Stephen C. Smith. (2015). Economic development. Pearson.

Mudrajad, Kuncoro. 2003. Pertumbuhan Ekonomi dan Ketimpangan Antar Kecamatan di Kabupaten Banyumas 1993-2000. JURNAL, Banyumasi

Nurlina, \& Chaira, T. M. I. (2017). Pengaruh Pertumbuhan Ekonomi Terhadap Distribusi Pendapatan di Provinsi Aceh. Jurnal Samudra Ekonomika, 1(2), 174-182.

Regita Puji Agustin, Adi Suparwo, Wulan Yuliyana, Denok Sunarsi, \& Nurjaya. (2021). Pengaruh Kualitas Pelayanan terhadap 
Kepuasan Pelanggan serta dampaknya pada Word of Mouth Jasa Pengurusan Nenkin di CV Speed Nenkin. JIIP - Jurnal Ilmiah Ilmu Pendidikan, 4(3), 186-190. Retrieved from http://jiip.stkipyapisdompu.ac.id/jiip/index .php/JIIP/article/view/249

Rifky, M. (2018). Analisis Pengaruh Produk Domestik Regional Bruto (PDRB), Kesenjangan Antar Daerah Dan Pembiyaan Sektor Pendidikan Terhadap Indeks Pembanguna Manusia Kabupaten/Kota Di Provinsi Jawa Timur. Jurnal Ilmu Ekonomi, 2, 312.
Robinson Tarigan. (2012). Perencanaan Pembangunan Wilayah. Bumi Aksara.

Sadono, Sukirno. 2011. Makroekonomi Teori Pengantar. Rajawali, Jakarta.

Sjafrizal, 2008. Ekonomi Regional,Teori Dan Aplikasi, Baduose Media, Padang

Sjafrijal. (n.d.). Ekonomi Regional, Teori dan Aplikasi (1st ed.). Baduose Media.

Subandi. (2012). Ekonomi Pembangunan. Alfabeta. 